\title{
The League of Nations and the international law of State responsibility
}

Antal Berkes*

\begin{abstract}
The League of Nations set up The Hague codification conference that focused, among three specific agendas, on the responsibility of states for damage caused in their territory to the person or property of foreigners. Scholarship has dominantly ignored or considered the work of the League of Nations in the law of state responsibility as a failure, starting the story of the codification with the International Law Commission. This article proposes to rethink the dominant view and claims that the League of Nations's codification process not only initiated, but substantially contributed to the codification of the law of state responsibility, leading to lasting methods, concepts, principles and norms that have been integrated in the contemporary canon of the rules of state responsibility.
\end{abstract}

\section{Keywords}

State responsibility, codification, attribution, circumstances precluding wrongfulness, protection of foreigners

\footnotetext{
* Lecturer in Law, Brunel University London.
} 


\section{Introduction}

Scholarship has dominantly ignored or negatively evaluated the work of the League of Nations (LoN) in the law of state responsibility, starting the story of the codification with the International Law Commission (ILC). As it is well-known, the ILC decided to begin the study of the topic of the responsibility of states in 1955, and in the subsequent almost half century, five different special rapporteurs prepared thirty-three reports on the topic, leading to the Articles on Responsibility of states for internationally wrongful acts (ARSIWA) as a final outcome in 2001. ${ }^{1}$ Compared to the gigantic codification work of the ILC, the contribution of the LoN to the law of state responsibility might seem both short-lived and negligible: from 1924 to 1930, it prepared and convened a four weeks-long conference in The Hague to elaborate the foundations of a convention on state responsibility for damage caused to the person or property of foreigners. The conference did not produce any draft treaty or report; commentators considered the State responsibility agenda as a 'failure'2 or 'the least successful' $^{3}$ compared to the two simultaneous codification agendas in The Hague on nationality and territorial waters that led to a treaty with three protocols and two recommendations on principles, respectively. ${ }^{4}$ Relying on this negative narrative, most manuals of public international law start the history of the law of state responsibility with the ILC's work, mentioning passim ${ }^{5}$ or ignoring ${ }^{6}$ the scene of The Hague codification attempt under the auspices of the LoN. This article proposes to rethink this dominant view and claims that the LoN's codification process not only initiated, but substantially contributed to the codification of the law of state responsibility, leading to lasting methods, concepts, principles

\footnotetext{
${ }^{1}$ Analytical Guide to the Work of the International Law Commission, available at: https://legal.un.org/ilc/guide/9 6.shtml\#fout (last accessed on 10 December 2019).

${ }^{2}$ Walter Simons, The Evolution of International Public Law in Europe since Grotius (1931) p. 84; Clémentine Bories, "The Hague Conference of 1930" in J. Crawford, A. Pellet and S. Olleson (eds.), The Law of International Responsibility (2010) pp. 64.

${ }^{3}$ Ramaa P. Dhokalia, The Codification of Public International Law (1970) p. 125.

${ }^{4}$ Ibid., p. 122-125.

${ }^{5}$ E.g. Antonio Cassese, International Law (2001) p. 183; Patrick Daillier and Alain Pellet, Droit international public (7th ed., 2002) p. 763.

${ }^{6}$ E.g. Peter Fischer and Heribert Franz Köck, Völkerrecht: Das Recht Der Universellen Staatengemeinschaft (6., durchgesehene und erw., 2004) p. 332-333; James Crawford and Simon Olleson, "The Character and Forms of International Responsibility" in M.D. Evans (ed.), International Law (2014) pp. 443-447; Robert Kolb, The International Law of State Responsibility: An Introduction (2018) p. 8-11; James Crawford, Brownlie's Principles of Public International Law (9th ed., 2019) p. 523-524.
} 
and norms that have been integrated in the contemporary canon of the rules of state responsibility.

The article proceeds as follows. Section 2 argues that through the organisation of the written and oral phases of The Hague codification conference, the LoN introduced lasting methods of codification that served as a model for the later work of the ILC. Section 3 discusses the general principles that The Hague conference set out while defining the responsibility of states, making it both a conceptualised and autonomous subject of international law. Those principles have formed the basis of the ARSIWA which recognise their LoN origin. The following two sections discuss particular norms debated in The Hague codification process and argue that those norms have contributed to the subsequent development of the contemporary rules of state responsibility. Section 4 examines one of the constitutive elements of state responsibility, attribution, and claims that The Hague conference established sound rules of attribution considered even nowadays as valid norms. Section 5 focuses on circumstances precluding wrongfulness that the LoN's codification process prepared to codify for the first time in the history of the discipline but could not discuss in sufficient details. The written and oral dialogue of states and experts on those general and particular concepts, principles or norms of state responsibility has established the foundations of a truly universal codification discussion that has continued until today. The conclusions will explain that the lasting impact of the LoN's codification in the international law of state responsibility confirms the pioneering work of the LoN.

\section{A Codification Experience}

The LoN's codification project on state responsibility was a learning experience, part of the first international law codification work within a purportedly universal international organisation. The LoN was the first intergovernmental organisation to announce its ambition to systematically codify international law and at the time it was considered as the legitimate subject to do so. While the Covenant did not grant it any competence in matter of the development or codification of international law, commentators argued that this followed form its general mandate to maintain international peace and security. ${ }^{7}$ The Covenant was itself

\footnotetext{
${ }^{7}$ Shabtai Rosenne, "Codification Revisited after 50 Years", 2 Max Planck Yearbook of United Nations Law (1998) pp. 1, 2; Jean Ray, Commentaire du Pacte de la Société des nations selon la politique et la jurisprudence des organes de la Société (1930) p. 85.
} 
viewed as a proper codification ${ }^{8}$ or the "Higher Law", 9 that is a treaty enshrining far-reaching obligations of states in the matter of international peace and security. Furthermore, there was a widespread feeling that the LoN could undertake codification of international law in an effective, timely manner. ${ }^{10}$

The first codification products of the LoN and the International Labour Organisation were technical conventions, considered as a continuation of an activity which had been practiced since the $19^{\text {th }}$ century through the formation of international unions in various domains (communications, literary artistic and industrial property, public health, and so forth). ${ }^{11}$ Based on five years' experience of the LoN, Sweden proposed the Assembly in 1924 to recommend the Council the codification of international law in certain matters. ${ }^{12}$ At the plenary meeting, the delegate of the Kingdom of Serbs, Croats and Slovenes relied on various sources of the LoN to justify its competence to undertake the codification of international law: Article 24 of the Covenant which considered the LoN as the lead of international administration, on the one hand, and the creation of the Permanent Court of International Justice (PCIJ) which supposed an obligation to define the substantive rules of international law, on the other. As he concluded, "[i]t is only natural that the LoN, being the most highly developed of existing international organisations, should assist in the establishment of rules of conduct to be observed by all States in their foreign relations". ${ }^{13}$

On 22 September 1924, the Assembly recognised the LoN's role in "meeting the legislative needs of international relations" and adopted a resolution on the "development of international law". ${ }^{14}$ The Assembly specifically requested the Council to convene a Committee of Experts which shall have the duty:

(1) To prepare a provisional list of the subjects of international law, the regulation of which by international agreement would seem to be most desirable and realisable at the present moment;

\footnotetext{
${ }^{8}$ P.J. Baker, "The Codification of International Law" (1924) 5 British Yearbook of International Law (1924) pp. 38, 54; Dhokalia, supra note 3, p. 113.

${ }^{9}$ Hersch Lauterpacht, "The Covenant as the Higher Law" 17 British Yearbook of International Law (1936) pp. 54.

${ }^{10}$ Baker (n 9) 58; Rosenne (n 8) 2-3.

118 League of Nations Official Journal, Special Supplement (1927) no. 7, pp. 750 (report of the Committee of Experts).

1223 League of Nations Official Journal, Special Supplement (1924) pp. 82-83 (Records of the $5^{\text {th }}$ Assembly, $12^{\text {th }} \mathrm{Pl}$. mtg.).

1323 League of Nations Official Journal, Special Supplement (1924) pp. 124.

${ }^{14} 21$ League of Nations Official Journal, Special Supplement (1924) pp. 10.
} 
(2) After communication of the list by the Secretariat to the Governments of States, whether Members of the League or not, for their opinion, to examine the replies received; and

(3) To report to the Council on the questions which are sufficiently ripe and on the procedure which might be followed with a view to preparing eventually for conferences for their solution. ${ }^{15}$

This has led to the creation of the Committee of Experts for the Progressive Codification of International Law. ${ }^{16}$ The Committee of Experts considered various subjects for codification, among which the responsibility of states for damage suffered within their territories by foreigners figured from the very beginning. ${ }^{17}$ In 1927 , based on the replies of various governments, the Committee of Experts recommended the Council seven subjects as being, in certain of their aspects, sufficiently ripe for discussion in international conference. Among them, the Committee of Experts considered that five important subjects might be the subject of an international conference or conferences after the necessary additional preparatory work has been performed. ${ }^{18}$ These topics included the "[r]esponsibility of States for Damage done in their Territory to the Person or Property of Foreigners". Based on the Council's report to the Assembly, adopted on 13 June 1927, the First Committee agreed to limit the codification project to three subjects: nationality, territorial waters and responsibility of states for damage caused in their territory to the person or property of foreigners. ${ }^{19}$ Regarding the question whether the future codification should be a mere registration of the law in force or an attempt to adapt it to practical needs, the Committee held that "while, in order to lead to useful results, the Conference must refrain from making too many innovations, it cannot limit itself to the mere registration of the existing law". ${ }^{20}$ Therefore, progressive development of the law of state responsibility was foreseen.

The law of state responsibility was elaborated as a subject of the law of nations by positivist pioneers such as Anzilotti and Triepel. ${ }^{21}$ Before The Hague codification conference, there were various international gatherings "sufficient to prove that unanimity can scarcely be

\footnotetext{
15 Ibid.

1633 League of Nations Official Journal, Special Supplement (1925) pp. 175-176.

${ }^{17}$ See the original list of 21 subjects in 1924: ibid., pp. 176(f); 6 League of Nations Official Journal (1925), no. 6, pp. 843(f).

18 "First Meeting (Private, and Then Public)" 8 League of Nations Official Journal (1927) pp. 751.

1954 League of Nations Official Journal, Special Supplement (1927) pp. 484-488, Annex 35.

${ }^{20}$ Ibid., pp. 487.

${ }^{21}$ Heinrich Triepel, Völkerrecht und Landesrecht (CL Hirschfeld 1899); Dionisio Anzilotti, Teoria Generale Della Responsabilità Dello Stato Nel Diritto Internazionale, vol I (F Lumachi, 1902).
} 
said to exist in regard to the general trend or the technique of the work of codification". ${ }^{22}$ In 1929, the Paris Conference on the Treatment of Foreigners attempted to codify the norms on the protection of foreigners, without any outcome document. ${ }^{23}$ Furthermore, codification of the law of State responsibility started simultaneously in regional, especially inter-American interstate instruments and private initiatives, and academic codifications. However, it was an essential intention of states to charge this time the world organisation with the codification: after the Netherlands undertook to host the conference, various delegations insisted that the LoN should not renounce its role in favour of a member state. ${ }^{24}$

In The Hague, state delegates were aware of the importance of the "theory of responsibility in any juridical system" and of its norms as "they key rules of any juridical system". ${ }^{25}$ International lawyers had abandoned the idea that the responsibility of the state is incompatible with sovereignty, as state responsibility for breaches of its obligations was widely recognised by state practice. For certain states in the interwar period, it seemed "obvious that the rules determining the extent and nature of the international responsibility of States in their mutual relations constitute one of the most important problems of international law". ${ }^{26}$

Beyond the search for universal norms fulfilling an aspiration for justice, the delegates in The Hague wished to answer to practical needs and identify "the rules which best meet the juridical needs of our time" in the field of state responsibility for damage to foreigners. ${ }^{27}$ In his opening speech, the Chairman of the meetings expressed the desirability to codify rules on this matter "as definite as possible". ${ }^{28}$

As a sign of the importance of the codification project, 47 states participated in the codification procedure, including nine countries that were not member states of the LoN and various non-European LoN member States (such as Latin-American States, India, Canada, Japan, Siam, South Africa, or Egypt as British protectorate). ${ }^{29}$

\footnotetext{
${ }^{22}$ Acts of the Conference for the Codification of International Law (The Hague, 1930), vol. IV: Meetings of the Committees. Minutes of the Third Committee (Responsibility of States), League of Nations Publications, V. Legal, document C.351(c)M.145(c).1930.V, 17 May 1930, pp. 18 (Mr d'Avila Lima, Portugal).

${ }^{23}$ John Ward Cutler, 'The Treatment of Foreigners in Relation to the Draft Convention and Conference of 1929' (1933) 27 American Journal of International Law 225.

${ }^{24} 55$ League of Nations Official Journal, Special Supplement (1927) pp. 19-21, Mr Lange (Norway), Mr Motta (Switzerland), Sir William Moore (Australia), Mr Rolin (Belgium).

${ }^{25}$ C.351(c)M.145(c).1930.V, supra note 22, pp. 15 (Mr Basdevant, Chairman).

${ }^{26}$ Ibid., pp. 19 (Mr Nagaoka, Japan).

${ }^{27}$ Ibid. (Mr Basdevant, Chairman).

${ }^{28}$ Ibid., pp. 15 (Mr Basdevant, Chairman).

${ }^{29}$ C.75.M.69.1929.V, Supplement to vol. III (Replies made by the Governments to the Schedule of points: Replies of Canada and the United States of America).
} 
The methods used by the Preparatory Committee reflected all the main tools that postWWII codification works have used: preparation of a report by a rapporteur (Sub-Committee) discussing basic principles in the subject-matter, ${ }^{30}$ the circulation of those principles and working papers called "bases of discussion" among states, the request of state commentaries, the evaluation of state views and the elaboration of draft articles by a drafting committee, with their subsequent submission to states. ${ }^{31}$ Furthermore, irrespective of the accomplishment of each of these stages during the codification process, in the late 1920s the LoN's initiative galvanized states' comments and private codifications by the very fact of its publicity. ${ }^{32}$

One must recognise that organisational deficiencies and the lack of independent expertise hindered a final outcome. After the Preparatory Committee adopted some articles on first reading, the Third Committee under the chairmanship of Jules Basdevant "was obliged to recognise that the time assigned for its work was not sufficient to allow it to bring a conclusion the studies which it had pursued with such assiduity". ${ }^{33}$ It could only discuss ten out of thirtyone bases of discussion submitted to it; many of them interrelated, and finally decided "to refrain from any endeavour to embody them in definitive formulae". ${ }^{34}$ Despite deficiencies and the lack of agreed outcome, the LoN's codification process has irreversibly implanted the idea of codifying the rules of state responsibility in the mind of international lawyers, together with well-established codification methods.

\section{General Principles}

Beyond the codification idea and methodology, the LoN has largely galvanised the development of international law in elaborating the basic principles of state responsibility. It

\footnotetext{
${ }^{30}$ LoN, Committee of Experts for the Progressive Codification of International Law. Annex: Report of the SubCommittee (Guerrero Report), C.46.M.23.1926.V, 9 February 1926, pp. 3-16.

${ }^{31}$ Ibid., pp. 17 (Mr Basdevant, Chairman) and 23 (Mr Guerrero, Salvador); on the process: Dhokalia (n 4) 112 133.

${ }^{32}$ Its impact is manifest in the academic codifications of the same period, e.g. Draft convention on the responsibility of States for injuries caused in their territory to the person or property of aliens, prepared by the German International Law Association, 1930, in: First report on State responsibility, by Mr. Roberto Ago, Special Rapporteur, vol. II YbILC, (1969) (First report of Ago), pp. 149-151, Annex VIII (1930 draft of the German International Law Association); Draft prepared by the Harvard Law School in 1929, in: vol. II YbILC, (1956) pp. 229-230 (Draft prepared by the Harvard Law School) and its commentary, "'Responsibility of States for Damage Done in Their Territory to the Person or Property of Foreigners' (1929) 23 Special Number Supplement to the American Journal of International Law 133, 140.

${ }^{33}$ Annex V: Draft report drawn up by the rapporteur, M. De Visscher (Belgium) at the Request of the Chairman, in: C.351(c)M.145(c).1930.V, supra note 22, pp. 238.

${ }^{34}$ Ibid.
} 
has contributed to the definition of the constitutive elements of state responsibility (section 3.1) and to the elimination of domestic law in the determination of state responsibility (section 3.2).

\subsection{Definition of State Responsibility}

Due to the conference's limitation to state responsibility for damage caused to the person or property of foreigners, there was no accepted definition of state responsibility at the beginning of the conference. The Preparatory Committee expressly inquired among states "what elements of wrongfulness must attach to the acts" attributable to the state "in order to render the State responsible". ${ }^{35}$ The bases of discussion answered this question generally: they provided that the state is responsible for the damage suffered by a foreigner when the state's conduct is contrary to the obligations imposed on that state by international law. ${ }^{36}$

State representatives in The Hague however did not start the discussions in a tabula rasa, but based on an old acceptance of state responsibility for the breach of international obligations through action or omission going back to Grotius. ${ }^{37}$ Moreover, despite the conference's focus on the protection of foreigners, the LoN's experts foresaw the codification of sufficiently general rules beyond this domain. ${ }^{38}$ Various delegates also expressed their readiness to codify the general rules of state responsibility. ${ }^{39}$

Some delegations suggested a broad definition foreseeing state responsibility to any failure to comply with international obligations, without requiring damage. ${ }^{40}$ Especially the French formula received much appreciation from the delegates, providing that "any failure on the part of the organs (legislative, executive or judicial) of a State to carry out the international

\footnotetext{
${ }^{35}$ C.75.M.69.1929.V, supra note 27, pp. 25.

${ }^{36}$ Bases Nos. 2. 5(2), 7, 12, 13 and 16.

${ }^{37}$ Hugo Grotius and AC Campbell, The Rights of War and Peace: Including the Law of Nature and of Nations (Autograph éd de luxe, MW Dunne 1901) 256 (Book I/Chapter XXI)., also cited at the conference: C.351(c)M.145(c).1930.V, supra note 22, pp. 33 (Mr d'Avila Lima, Portugal).

${ }^{38}$ See the level of abstraction in the Guerrero report, supra note 28, pp. 4-5, 7; Progressive codification of international law. Report of the Committee of Three Jurists appointed by the Council on December $14^{\text {th }}, 1928$, C.171.(I).1929.V, 25 June 1929, p. 3 (distinguishing between the subject 'international responsibility of States' and the 'question of damage caused in their territory to the person or property of foreigners [...] to be dealt with at The Hague Conference for the Progressive Codification of International Law').

${ }^{39}$ Eg C.351(c)M.145(c).1930.V, supra note 22, pp. 89 (Mr Richter, Germany), 91 (Mr Matter, France), 93 (Mr d'Avila Lima, Portugal).

${ }^{40}$ Ibid., pp. 24 (Mr Matter, France), 25 (Mr Richter, Germany), 27 (Romania; Mr Guerrero, Salvador).
} 
obligations of that State involves its responsibility". ${ }^{4142}$ France considered this principle as reflecting the existing law $^{43}$ and the delegates adopted it unanimously. ${ }^{44}$

This draft Article 1 adopted in first reading at the French proposal was specified to the context of the protection of foreigners and required damage:

International responsibility is incurred by a State if there is any failure on the part of its organs to carry out the international obligations of the State which causes damage to the person or property of a foreigner on the territory of the State. ${ }^{45}$

Other delegations proposed a provision on the reparation that the responsible state shall make for the damage suffered by a foreigner. ${ }^{46}$ The principle that any internationally wrongful act entails a legal obligation of reparation had been soundly established in international case law at the time and The Hague codification conference also confirmed it in its draft Article 3 adopted on first reading. ${ }^{47}$

Before The Hague Conference, scholarship was however divided between the subjectivist theory of fault $\mathrm{t}^{48}$ and the objectivist theory requiring the mere wrongfulness for responsibility. ${ }^{49}$ The former, requiring intentional (dolus) or negligent (culpa) conduct on the part of the state agent while committing the wrongful act, dominated international law theory on state responsibility from the $17^{\text {th }}$ until the early $20^{\text {th }}$ century. ${ }^{50}$ There were even few precedents in the early $20^{\text {th }}$ century following the fault theory. ${ }^{51}$ However, theorists like Triepel and Anzilotti persuasively purified the law of State responsibility from considerations of culpability, ${ }^{52}$ and the dominant case law supported their views, reducing responsibility to the

\footnotetext{
${ }^{41}$ Case concerning the Factory at Chorzów, PCIJ Ser. A, no. 17.

${ }^{42}$ Ibid., p. 24.

${ }^{43}$ Ibid., p. 30 (Mr Matter, France).

44 Ibid., p. 31.

${ }^{45}$ C.351(c)M.145(c).1930.V, supra note 22, Annex IV: Text adopted by the Committee in first reading as revised by the Drafting Committee, pp. 236-237 (Text adopted in first reading), Article 1.

${ }^{46}$ C.351(c)M.145(c).1930.V, supra note 22, pp. 27 (South Africa), 28 (Mr Hackworth, USA).

${ }^{47}$ Text adopted in first reading, supra note 45, pp. 236, Article 3.

${ }^{48}$ E.g. Jacques Dumas, 'La Responsabilité Des Etats à Raison Des Crimes et Délits Commis Sur Leur Territoire Au Préjudice d'étrangers' 36 Recueil des cours de l'Académie de droit international de La Haye 187, $211-213$. ${ }^{49}$ See a summary of the different authors in: Clyde Eagleton, The Responsibility of States in International Law (New York University Press 1928) 208-213.

${ }^{50}$ Andrea Gattini, Zufall Und Force Majeure Im System Der Staatenverantwortlichkeit Anhand Der ILCKodifikationsarbeit (Duncker \& Humblot 1991) 18-20.

${ }^{51}$ See at the end of $19^{\text {th }}$ century state practice in Chile, Venezuela and Brazil, in: Pierre-Marie Dupuy, "Le fait generateur de la responsabilite' intemationale des. Etats", $R d C(1984-\mathrm{V})$ pp. $61 \mathrm{ff}$.; a later case arguably relying on culpa is the case of Home Missionary Society, UNRIAA, 1920, vol. 6, p. 42 (no government is responsible for the acts of rebels where it itself was guilty of no breach of good faith or negligence in suppressing the revolt).

52 Triepel (n 22) 334; Anzilotti (n 22) 136.
} 
mere wrongful act of the state. ${ }^{53}$ The debate persisted in the interwar period and even three years before The Hague, the Institute of International Law's discussions showed the division of the scholarship on the issue,${ }^{54}$ and led to a resolution requiring fault in the definition of state responsibility for damage caused to foreigners, depending on the given primary law obligation. ${ }^{55}$ The scholarly debate was mentioned in The Hague too, ${ }^{56}$ but as the Rapporteur, Charles De Visscher, opposed the psychological or moral understanding of fault and accepted the notion simply as the violation of an international obligation, ${ }^{57}$ his pragmatism influenced the working definition accepted. The pragmatic decision in The Hague to eliminate the culpadebate also anticipated the ILC's nuanced view on the issue: under Articles 2 and 12 ARSIWA, state responsibility does not require fault before the characterization of the conduct as internationally wrongful, but in the given case the concerned primary norm obligation might foresee fault for its violation. ${ }^{58}$ This is the case especially with state responsibility for omissions where considerations of intention and knowledge matter. ${ }^{59}$

Another dividing line was the inclusion of damage in the content of state responsibility: whereas certain commentators required damage for state responsibility, ${ }^{60}$ others did not consider it as a defining element. As most codifications similar to that of The Hague focused on state responsibility related to damage caused to foreigners, damage was considered part of the primary law violation. The report of the Sub-Committee charged with the preparation of the LoN's codification also held that damage only arises in "certain circumstances" because "damage does not per se imply international responsibility. For international responsibility to exist, the damage must be the result of a violation, by the State itself, of some international rule". ${ }^{61}$ The fact that the discussions did not specifically conceptualise damage as an element

\footnotetext{
${ }^{53}$ See various decisions cited in: Eagleton (n 50).; Draft prepared by the Harvard Law School, supra note 30.

${ }^{54}$ Annuaire de l'Institut de droit international, (1927) pp. 103-107,

${ }^{55}$ Institute of International Law, Resolution of 1927 at the session of Lausanne, Draft on "international responsibility of States for injuries on their territory to the person or property of foreigners", reported in: vol. II YbILC (1956) pp. 227-229, Article I(4) ("This responsibility of the State does not exist if the lack of observance of the obligation is not a consequence of a fault of its organs, unless in the particular case a conventional or customary rule, special to the matter, admits of responsibility without fault.").

${ }^{56}$ E.g. against the subjective culpa: C.351(c)M.145(c).1930.V, supra note 22, pp. 86 (Mr Lansdown, South Africa), 98 (Mr Limburg, Netherlands).

${ }^{57}$ Annuaire de l'Institut de droit international, supra note 52, pp. 106; Charles De Visscher, 'Notes Sur La Responsabilité Des États et La Protection Diplomatique d'après Quelques Documents Récents' (1927) 8 Revue de droit international et de législation comparée 245, 252.

${ }^{58}$ Draft articles on Responsibility of States for Internationally Wrongful Acts, with commentaries, vol. II(2) YbILC, (2001) [ARSIWA Commentary], pp. 34-35, para. 3; pp. 36, para. 10 and pp. 54-55, para. 2; James Crawford, State Responsibility: The General Part (Cambridge University Press 2013) 93, 113-114, 217-220.

${ }^{59}$ E.g. in this sense: Corfu Channel case, Judgment of April 9th, 1949, I.C.J. Reports 1949, p. 18.

${ }^{60}$ Paul Fauchille, Traité de Droit International Public, vol 1: Paix (A Rousseau \& Cie 1922) 515; AG Heffter, Le Droit International Public de l'Europe (Jules Bergson tr, 3rd edn, Cotillon et fils 1873) 200.

${ }^{61}$ Guerrero report, supra note 28, pp. 6.
} 
of state responsibility implied the present dominant view under which damage is a consequence of the content of the primary obligation rather than constitutive element of state responsibility. ${ }^{62}$

After the LoN's codification process, most commentators defined state responsibility as the consequence of a violation of international law obligations, ${ }^{63}$ without considering subjective fault or damage as definitional elements of secondary norms.

\subsection{Irrelevance of Domestic Law in Determining State Responsibility}

It was not an accident that the very first point of discussion that the Preparatory Committee of the Conference for the Codification of International Law drew up in 1929 was the irrelevance of domestic law in the determination of state responsibility for the damage caused to foreigners. Under the text of the first point of discussion, "a State cannot escape its responsibility under international law by invoking the provisions of its municipal law." ${ }^{64}$ Quite ambiguously, the Preparatory Committee inserted the provision at the beginning of the chapter title "[c]ircumstances under which States can decline their responsibility", ${ }^{65}$ while it was clear for states that the provision excluded the invocation of domestic law as falling under this category of cases.

The rule's pedigree goes back to the Alabama Claims Arbitration award ${ }^{66}$ confirmed by other arbitral decisions in the interwar period. ${ }^{67}$ By 1930, the PCIJ had also firmly established the rule according to which conformity with the provisions of internal law in no way precludes conduct being characterized as internationally wrongful. ${ }^{68}$ In its resolution on

\footnotetext{
${ }^{62}$ ARSIWA Commentary, supra note 56, pp. 36, para 9.

${ }^{63}$ E.g. Maurice Bourquin, 'Règles Générales Du Droit de La Paix' (1931) 35 Recueil des cours de l'Académie de droit international de La Haye 5, 212; Karl Strupp, 'Les Règles Générales Du Droit de La Paix' (1934) 47 Recueil des cours de l'Académie de droit international de La Haye 263, 557-558; Jules Basdevant, 'Règles Générales Du Droit de La Paix' (1936) 58 Recueil des cours de l'Académie de droit international de La Haye 475,668 .

${ }^{64}$ C.75.M.69.1929.V, supra note 27, pp. 16.

${ }^{65}$ C.351(c)M.145(c).1930.V, supra note 22, pp. 201.

${ }^{66}$ Alabama claims of the United States of America against Great Britain, 14 September 1872, UNRIAA, vol. XXIX, p. 131 ('And whereas the judicial acquittal of the Oreto at Nassau cannot relieve Great Britain from the responsibility incurred by her under the principles of international law').

${ }^{67}$ See the examples cited by Ago in: Third report on State responsibility, by Mr. Roberto Ago, Special Rapporteur-The internationally wrongful act of the State, source of international responsibility, vol. II(1) YbILC, (1971) pp. 228-229, para. 95.

68 S.S. 'Wimbledon', 1923, PCIJ, Series A, No. 1, pp. 29-30; Greco-Bulgarian 'Communities', Advisory Opinion, 1930, PCIJ, Series B, No. 17, pp. 32; Free Zones of Upper Savoy and the District of Gex, Order of 6 December 1930, PCIJ, Series A, No. 24, pp. 12; and ibid., Judgment, 1932, PCIJ, Series A/B, No. 46, pp. 167; Treatment of Polish Nationals and Other Persons of Polish Origin or Speech in the Danzig Territory, Advisory Opinion, 1932, PCIJ, Series A/B, No. 44, pp. 24.
} 
state responsibility adopted in 1927 , the Institute of International Law found it necessary to expressly provide on the irrelevance of domestic law in the determination of international responsibility. ${ }^{69}$ As private codifications also adopted provisions in a similar sense ${ }^{70}$ The Hague codification conference had good reasons not to overlook the increased international consensus about the rule.

Most states were in favour of this principle, ${ }^{71}$ while few expressed specific reservations. France stressed that the decisions of the French courts concerning the responsibility of the state for damage caused to foreigners are based on municipal and not international law. ${ }^{72}$ Romania could not accept a supposed "existence of an international law on a higher plane than the constitution and internal laws of the various States". ${ }^{73}$ Beyond those views, the Third Commission concluded that the government replies showed "unanimous acceptance of the idea that the responsibility of a State under international law for damage caused on its territory to the person or the property of foreigners is distinct from its responsibility under its own laws". ${ }^{74}$ It concluded that there was no need to express this idea in the proposed Convention, and adopted the text as follows: "A State cannot escape its responsibility under international law by invoking the provisions of its municipal law". 75

As the responsibility of the state for unlawful conduct towards its own citizens was at the time not yet regulated by international law and was only codified after the Second World War, especially in line with international human rights treaties, states distinguished between the states municipal responsibility and international responsibility. ${ }^{76}$

Some delegates considered Basis No. 1 "as a statement of principle' that expresses 'the idea that the laws of a State must conform to the rules of international law". ${ }^{77}$ Even though

\footnotetext{
${ }^{69}$ Institute of International Law at Lausanne in 1927, Article I(2), in: vol. II YbILC, (1956) pp. 227-229; See the discussions in Annuaire de l'Institut de droit international, supra note 52, pp. 96-98.

${ }^{70}$ E.g. draft code prepared by the Japanese Association of International Law in 1926, Article 5, in: First report on State responsibility, by Mr. Roberto Ago, Special Rapporteur, vol. II YbILC, (1969) (First report of Ago), pp. 141, annex II; Institute of International Law, Resolution of 1927, supra note 55, Article IX(1); Draft prepared by the Harvard Law School, supra note 32; 1930 draft of the German International Law Association, supra note 32, pp. 150 .

${ }^{71}$ E.g. C.75.M.69.1929.V, supra note 29, pp. 18 (Poland), 19 (Czechoslovakia) (Point 1/Basis of discussion 1); ibid., Supplement to vol. III, pp. 4 (U.S.A.).

${ }^{72}$ Ibid., pp. 17.

${ }^{73}$ Ibid., pp. 18.

${ }^{74}$ Ibid., pp. 19.

${ }^{75}$ Ibid.

${ }^{76}$ C.351(c)M.145(c).1930.V, supra note 22, pp. 121, Mr. d'Aliva Lima (Portugal); C.75.M.69.1929.V (n 29), p. 17 (Hungary).

${ }^{77}$ C.351(c)M.145(c).1930.V, supra note 22, pp. 121, Mr. Novakovitch (Yugoslavia).
} 
there was a wide support for the principle, some states insisted to its non-applicability to a "domaine réservé", that is the reserved domain of national sovereignty. ${ }^{78}$ This reflected the contemporary debate about the reach of international law. Commentators accepting the existence of a "domaine réservé", not subject to international norms, relied on Article 15(8) of the LoN's Covenant. Under that provision, "[i]f the dispute between the parties is claimed by one of them, and is found by the Council, to arise out of a matter which by international law is solely within the domestic jurisdiction of that party, the Council shall so report, and shall make no recommendation as to its settlement". Various dispute settlement bodies of the LoN interpreted the notion "domaine réservé" ("solely within the domestic jurisdiction of that party") throughout the years: they clarified that it relates to subject matters not regulated by international law and thus "depends upon the development of international relations". ${ }^{79}$ They also pointed out that the decision whether a subject matter falls within the reserved domains lies with the Council ${ }^{80}$ or, without its intervention, international judges. ${ }^{81}$ The PCIJ held that Article 15(8) of the Covenant, which protects the independence of states, is an exception to the principles of peaceful settlement of disputes in the LoN under Article 15 "and does not therefore lend itself to an extensive interpretation". 82 The LoN's Committee of Jurists excluded from the reach of the reserved domains the transition from a de facto situation to a de jure situation in the acquisition of statehood, ${ }^{83}$ while the Court considered other subject matters such as nationality ${ }^{84}$ or the discretionary submission of disputes to the $\mathrm{PCIJ}^{85}$ as "domaines réservés".

The PCIJ, however, made it clear that Article 15(8) does not enable states to exempt any subject matter from the reach of international law, but is limited to "certain matters which, though they may very closely concern the interests of more than one State, are not, in principle, regulated by international law". ${ }^{86}$ In The Hague, some delegates like the Greek Politis stressed this aspect, noting that the state could by definition incur no responsibility in its conduct within

\footnotetext{
${ }^{78}$ Ibid., pp. 124, Mr. Simpson (Romania).

${ }^{79}$ Nationality Decrees Issued in Tunis and Morocco on Nov. 8th, 1921, Advisory Opinion, 1923, PCIJ, Series B, No. 4, pp. 23-24.

${ }^{80}$ LoN, Report of the International Committee of Jurists entrusted by the Council of the League of Nations with the task of giving an advisory opinion upon the legal aspects of the Aaland Islands question. League of Nations Official Journal Special Supplement, October 1920, no. 3 (Aaland Islands Question), p. 4.

${ }^{81}$ Ray (n 8) 492.

${ }^{82}$ Nationality Decrees Issued in Tunis and Morocco, supra note 79, pp. 25.

${ }^{83}$ Aaland Islands Question, supra note 80, pp. 6.

${ }^{84}$ Nationality Decrees Issued in Tunis and Morocco, supra note 79, pp. 24.

${ }^{85}$ Mavrommatis Palestine Concessions (Greece v. U.K.), 1924, PCIJ, Series B, No. 3, pp. 16-17.

${ }^{86}$ Nationality Decrees Issued in Tunis and Morocco, supra note 79), pp. 23-24.
} 
a reserved domain, where there can be no international obligation. ${ }^{87}$ This aspect convinced the delegations and the proposal on a reference to the reserved domain was omitted. ${ }^{88}$

Another proposed modification aimed to complement municipal law as a prohibited ground for escaping state responsibility with another prohibited ground, the lack of enforcement machinery to implement the state's international obligations. ${ }^{89}$ The South African delegate had in mind a scenario where domestic law a priori complies with international law, but no executive machinery supports its implementation. Therefore, concluded the delegate, the state could invoke this enforcement deficiency to escape its international obligations. ${ }^{90}$ While the Belgian delegate proposed to address this scenario by the amended reference to "by invoking the provisions or deficiencies of its municipal law", ${ }^{91}$ the Greek representative proposed the wording "by invoking the state of its municipal law" as a compromise solution. ${ }^{92}$ The latter amendment was adopted by the delegates. ${ }^{93}$ In turn, the Drafting Committee proposed to suppress the words "the state of" which it put in brackets, and the text adopted by the Committee in first reading (Draft Article 5) provided as follows: "[a] State cannot avoid international responsibility by invoking (the state of) its municipal law". ${ }^{94}$

Other delegations found the provision reasonable, but useless as they considered it repeating the basis of Discussion No. 2 on the state's responsibility for the acts and omissions of its legislative power. ${ }^{95}$ Their proposal to remove the provision was rejected by 19 votes to 13, which shows nonetheless a strong support for their view. It is not surprising that in the 1930s, scholars did not contest the rule as applying in all fields of state responsibility. ${ }^{96}$ The long-term impact of the provision discussed and agreed on in The Hague is well-known: contemporary and subsequent codifications, ${ }^{97}$ and the consecutive ILC special rapporteurs on state responsibility have adopted the same rule, referring to The Hague codification. ${ }^{98}$ In 1968 ,

\footnotetext{
${ }^{87}$ C.351(c)M.145(c).1930.V, supra note 22, pp. 126, Mr. Politis (Greece).

${ }^{88}$ Ibid., pp. 126.

${ }^{89}$ Ibid., pp. 124, Mr. Lansdown (South Africa).

${ }^{90}$ Ibid., pp. 128, Mr. Lansdown (South Africa).

${ }^{91}$ Ibid., pp. 125, Mr.De Visscher (Belgium).

92 Ibid., pp. 127, Mr. Politis (Greece).

93 Ibid., pp. 128.

${ }^{94}$ Ibid., pp. 236.

${ }^{95}$ Ibid., pp. 121, Mr. Suarez (Mexico) and p. 125, Mr. Urrutia (Colombia).

${ }^{96}$ Constantin Th Eustathiades, 'La Responsabilité Internationale de l'État Pour Les Actes Des Organes Judiciaires et Le Problème Du Déni de Justice En Droit International' (Paris 1936) 354.

${ }^{97}$ E.g. 1930 draft of the German International Law Association, supra note 32, Article 7(2)(2)-(3); Draft convention on the responsibility of States for international wrongful acts, prepared by Professor Roth in 1932, in: ibid., 152, Annex X, Article 4; Draft prepared by the Harvard Law School, supra note 32, Article 2(2). ${ }^{98}$ E.g. Third report on State responsibility, supra note 65, pp. 226-233, paras 86-105 (Draft Article 4).
} 
the ILC included the same rule in the draft Convention on the Law of Treaties, the later Article 27 of the Vienna Convention. ${ }^{99}$ With slightly different wording, Article 3 ARSIWA codified the rule on the characterization of an act of a state as internationally wrongful under international law only, irrespective of its lawfulness under domestic law. As a sign of continuity, the Commentary of Article 3 ARSIWA cites the provision and the debates of the 1930 Codification conference. ${ }^{100}$

\section{Attribution}

Attribution of conduct was very early recognised as part of the law of international responsibility, ${ }^{101}$ but only conceptualised at the end of the $19^{\text {th }}$ century. ${ }^{102}$ In the LoN's codification process, the preparatory report of the Sub-Committee and state delegates recognised attribution as a constitutive element of state responsibility ${ }^{103}$ and elaborated certain attribution norms. Discussions on the conduct of state organs (section 4.1), non-state actors (section 4.2) and states subordinated to another state (section 4.3) have long-term influenced the development of international law.

\subsection{State Organs}

Private codifications elaborated before The Hague conference rarely provided on the attributability of conduct of state organs ${ }^{104}$ and very few instruments detailed how far such conduct is attributable to the state. ${ }^{105}$ As the first state-led codification discussing these questions, the LoN's codification process has largely contributed to the legal development.

\footnotetext{
${ }^{99}$ Official Records of the United Nations Conference on the Law of Treaties, Second Session, Summary records of the plenary meetings and of the meetings of the Committee of the Whole (United Nations publication, Sales No. E.70.V.6), $13^{\text {th }}$ meeting, pp. 53-54, paras. 30-40.

${ }^{100}$ ARSIWA Commentary, supra note 58, pp. 37, para. 5; see also Article 32 ARSIWA.

${ }^{101}$ Richard Zouch, Iuris et Iudicii Fecialis, Sive, Iuris Inter Gentes, et Quaestionum de Eodem Explicatio: Qua Quae Ad Pacem \& Bellum Inter Diversos Principes, Aut Populos Spectant, Ex Praecipuis Historico-IurePeritis, Exhibentur (Carnegie Institution of Washington 1911) 106-107.

${ }^{102}$ Triepel, supra note 52, p. 324-371.

${ }^{103}$ E.g. Guerrero report, supra note 30, pp. 6, 15; C.351(c)M.145(c).1930.V, supra note 22, pp. 87 (Mr Guerrero, Salvador).

${ }^{104}$ Institute of International Law, Resolution of , supra note 55, Articles I(2): “This responsibility of the State exists even when its organizations act contrary to the law [...]", and II: "“The State is responsible for the act of corporate bodies exercising public functions on its territory."; Draft prepared by the Harvard Law School, supra note 32, Article 7(a): "A state is responsible if an injury to an alien results from the wrongful act or omission of one of its higher authorities within the scope of the office or function of such authority [...]", and (b): "“wrongful act or omission of one of its subordinate officers or employees within the scope of his office or function [...]". ${ }^{105}$ Ibid., Article I(3) (ultra vires conduct).
} 
In the consultation process, there was a consensus of states that led to basis of Discussion No. 12, which provided that:

A state is responsible for damage suffered by a foreigner as the result of acts or omissions of its officials, acting within the limits of their authority, when such acts or omissions contravene the international obligations of the State. ${ }^{106}$

States almost unanimously accepted attribution of conducts of the state's officials to that state when acting within the limits of their authority. ${ }^{107}$ Similarly, all states agreed that "[a]cts or omissions of bodies exercising public functions of a legislative or executive character (communes, provinces, etc.)", that is "corporate entities (communes, provinces, etc.) or autonomous institutions as exercise public functions of a legislative or administrative character" are attributable to the state within which they operate. ${ }^{108}$ Finding an agreement among states about the meaning of state organs was a novelty in international instruments.

The common denominator of states' views became the above-mentioned draft Article 1 adopted in first reading, stipulating the state's responsibility for the wrongful acts "of its organs". ${ }^{109}$ This was the first use of the term "organ" in the history of the codification of state responsibility, also adopted by the subsequent ILC rapporteurs. ${ }^{110}$ As it is well-known, Article 4 ARSIWA has confirmed draft Article 1 of The Hague codification conference and its commentary equally referred to the LoN's above-mentioned codification drafts. ${ }^{111}$

Beyond the rule on the automatic attributability of state organs' conducts, The Hague codification drafts also included rules on public powers delegated to persons not having the quality of state organ. Some states indicated strong support for the attribution to the state of the conduct of autonomous bodies exercising public functions of an administrative or legislative character. ${ }^{12}$ Consequently, the Preparatory Committee foresaw the principle under which a state is responsible for damage suffered by a foreigner as the result of internationally wrongful act of "such [...] autonomous institutions as exercise public functions of a legislative or administrative character". ${ }^{113}$ This constituted the early origin of the later Article 5 ARSIWA,

\footnotetext{
${ }^{106}$ LoN, Conference for the Codification of International Law, Bases of Discussion for the Conference drawn up by the Preparatory Committee, vol. 3, Doc. C.75.M.69.1929.V, 3 May 1929, p. 74.

${ }^{107}$ C.75.M.69.1929.V, supra note 106, pp. 70- , the exception being Hungary, p. 72.

${ }^{108}$ Ibid., pp. 90-92 (Basis of Discussion No. 16).

109 Text adopted in first reading, supra note 45, Article 1.

${ }^{110}$ E.g. ILC, Fourth report on State responsibility, by Mr. Roberto Ago, Special Rapporteur, vol. II YbILC, (1972) pp. 72, para. 1.

${ }^{111}$ ARSIWA Commentary, supra note 58, pp. 40, para. 4 and p. 41, para. 8 .

${ }^{112}$ C.75.M.69.1929.V, supra note 106, pp. 90 (Germany).

${ }^{113}$ Ibid., pp. 92 (Basis of Discussion No. 16).
} 
namely the attribution of the conduct of persons or entities exercising elements of governmental authority. ${ }^{114}$

Moreover, the Preparatory Committee addressed the question of ultra vires wrongful acts, that is the attributability of conducts exceeding the competence of State organs, providing in its basis of Discussion No. 13 that:

[a] State is responsible for damage suffered by a foreigner as the result of acts of its officials, even if they were not authorised to perform them, if the officials purported to act within the scope of their authority and their acts contravened the international obligations of the State. ${ }^{115}$

In The Hague, most states confirmed this rule, ${ }^{116}$ although certain states questioned whether ultra vires conduct would only attenuate or entirely exclude the state's responsibility. ${ }^{117}$

Some of the states, which did not accept this attribution, seemed to merge ultra vires conducts, on the one hand, and conducts manifestly unconnected with the official capacity of the agent, on the other. ${ }^{118}$ They did not accept state responsibility for ultra vires conduct, as they considered it merely private act. ${ }^{119}$ Most states however clearly distinguished those two cases and held that contrary to ultra vires conducts, attributable to the state, conducts manifestly unconnected with the official capacity are not attributable to the state. ${ }^{120}$ When the Preparatory Committee expressly asked the states' views about conducts of officials unconnected with their official duties, most representatives denied that attribution could arise. $^{121}$

Due to the frequency of state agents' unauthorised conducts, the Preparatory Committee held that "a rule restricting responsibility to the acts of officials acting within the scope of their authority would be inadequate". ${ }^{122}$ Likewise, it concluded from the written observations of states that an act performed by an official of a state "within the apparent scope" of his or her

\footnotetext{
${ }^{114}$ Article 5 ARSIWA and ARSIWA Commentary, supra note 58, pp. 43, para. 4 citing The Hague conference.

115 C.75.M.69.1929.V, supra note 106, pp. 78.

${ }^{116}$ Ibid., pp. 74-82; C.351(c)M.145(c).1930.V, supra note 22, pp. 93-94 (Mr Latifi, India), 97 (Mr Limburg, Netherlands).

${ }^{117}$ C.75.M.69.1929.V, supra note 106, pp. $73-74$ (Switzerland); C.351(c)M.145(c).1930.V, supra note 22, pp. 87-88 (Mr Guerrero, Salvador, excluding State responsibility for ultra vires conduct).

${ }^{118}$ C.75.M.69.1929.V, supra note 106, pp. 75 (Austria, Bulgaria).

119 Ibid., pp. 77 (Poland, Czechoslovakia), 81 (Czechoslovakia).

${ }^{120}$ Ibid., pp. 52 (Germany), 71 (Bulgaria), 76 (Finland), 80 (Japan); C.351(c)M.145(c).1930.V, supra note 22, pp. 85 (Mr, Lansdown, South Africa), 87 (Mr Nagaoka, Japan), 94-95 (Mr Dinichert, Switzerland), 96 (Mr Matter, France).

${ }^{121}$ C.75.M.69.1929.V, supra note 106, pp. 82-85.

122 Ibid., pp. 78.
} 
authority in a foreign country (a diplomatic agent, a consul) must be considered act of the state. $^{123}$

The text adopted by the Committee in first reading reflected the majority view on the attributability of ultra vires conduct, and the non-attribution of apparent ultra vires conduct. The adopted draft Article 8 provided:

International responsibility is incurred by a State if damage is sustained by a foreigner as a result of acts or omissions of its officials, acting within the limits of their authority, when such acts or omissions contravene the international obligations of the State.

International responsibility is likewise incurred by a State if damage is sustained by a foreigner as a result of unauthorized acts of its officials performed under cover of their official character, if the acts contravene the international obligations of the State.

International responsibility is, however, not incurred by a State if the official's lack of authority was so apparent that the foreigner should have been aware of it and could, inconsequence, have avoided the damage ${ }^{124}$.

As a sign of its long-term effect, the commentary of Article 7 ARSIWA expressly cites Draft Article $8(2)^{125}$ and recognises the difficulty to draw the line between unauthorised but still "official" conduct, on the one hand, and conduct removed from official functions, on the other. $^{126}$

\subsection{Non-state Actors}

Codifications and case law before 1930 recognised that the state is not responsible for wrongs caused by non-state actors, especially individuals or rebels. ${ }^{127}$ A Special Commission of Jurists constituted by the LoN in the Tellini case in 1924 also adopted the principle according to which the state bears no responsibility for the wrongful conduct of private persons unless it breached its own primary obligations to prevent. ${ }^{128}$

\footnotetext{
${ }^{123}$ Ibid, pp. 82, Basis for Discussion No. 14.

${ }^{124}$ Text adopted in first reading, supra note 45, 236-237, Article 8.

${ }^{125}$ ARSIWA Commentary, supra note 58, pp. 45-46, para. 3.

126 Ibid., pp. 46, para. 7.

${ }^{127}$ Convention relative to the rights of aliens signed at the second international conference of American States (Mexico City, 1902), in: vol. II YbILC (1956) pp. 226, Annex 5, para. 2; Institute of International Law, Resolution of 1927, supra note 55, Articles III and VII; Draft prepared by the Harvard Law School, supra note 32, Article 11.

${ }^{128}$ League of Nations Official Journal (1924), no. 4, p. 524.
} 
In the LoN's codification process, states agreed that the conduct of private individuals is not attributable to the state, ${ }^{129}$ while certain states put the emphasis on the state's responsibility for its own omission. According to the latter focus, the state incurs responsibility for the violation of its own due diligence obligation to take reasonable measures within the limits of its power to prevent and repress wrongful conducts. ${ }^{130}$ The Preparatory Committee adopted this majority view as one of the articles:

As regards damage caused to foreigners or their property by private persons, the State is only responsible where the damage sustained by the foreigners results from the fact that the State has failed to take such measures as in the circumstances should normally have been taken to prevent, redress, or inflict punishment for the acts causing the damage. $^{131}$

A special case of the state's non-responsibility for the conduct of individuals is the wrongful acts of insurgents, confirmed by the basis of Discussion No. 22 drafted by the Preparatory Committee. For the damage caused by unsuccessful insurrectional movements, most states agreed that the state does not incur responsibility through attribution. ${ }^{132}$ Most states also reiterated that the state is responsible for the omission to comply with its own due diligence obligation to take all reasonable measures within its power. Various states added that responsibility arises however if the state pays compensation only to its own nationals but not to foreigners, based on a norm on the equal treatment of foreigners and nationals, ${ }^{133}$ considered by certain former codifications as a rule of state responsibility. ${ }^{134}$ The agreement of the states on the non-responsibility for the damage caused by insurgents as a main rule led the Preparatory Committee to conclude that "[i]n principle, the replies do not admit that a State is responsible for damage caused to foreigners by insurgents, rioters or mob violence". ${ }^{135}$

However, where the insurrectional movement is successful and installed in power, state comments held that the state shall be responsible for the wrongful acts of the insurrectional movement. ${ }^{136}$ Few states were of the contrary view: for instance, the Netherlands doubted "whether the insurgent party can be held responsible for acts committed previous to its

\footnotetext{
${ }^{129}$ Eg C.75.M.69.1929.V, supra note 106, pp. 21 (Bulgaria), 93 (South Africa, Germany), 95 (Japan, Norway).

${ }^{130}$ Ibid., Basis of Discussion No. 17, pp. 93-96.

${ }^{131}$ Text adopted in first reading, supra note 45 pp. 236-237, Article 10.

${ }^{132}$ C.75.M.69.1929.V, supra note 106, Basis of Discussion No. 22, pp. 108-120.

${ }^{133}$ Ibid., e.g. pp. 108 (South Africa, Australia), 109 (Belgium, Finland, Great Britain), 110 (Hungary) and 114116 (Basis of Discussion No. 22(b)).

${ }^{134}$ E.g. Institute of International Law, Resolution of 1927, supra note 55, Article 4.

${ }^{135}$ C.75.M.69.1929.V, supra note 106, pp. 111.

${ }^{136}$ Ibid., pp. 116-118 (Point IX(c)/Basis of discussion 22(c)) and 109 (Great Britain).
} 
assumption of power". ${ }^{137}$ Contrary to this minority view, other states such as Switzerland expressly recognised the principle of continuity under which "every Government must be responsible for the acts of its predecessors". ${ }^{138}$ Certain states even distinguished between two scenarios of successful insurrections: when the movement is incorporated into a new state or another state, on the one hand, and when it overthrows government of the state and installs in power, on the other. ${ }^{139}$ The support of most delegations in the LoN for the state's responsibility in case of successful insurrectional movements was at the time not obvious. In 1927, the codification of the Institute of International Law on state responsibility reserved the question with a huge majority. ${ }^{140}$

The Preparatory Committee concluded that both commenting States and the case law recognise that in case of a successful insurrection:

the State is responsible for the acts of the insurrectionist party to at least the extent to which it is responsible for the acts of the legal Government and its agents. The question is raised whether one should not go further and consider the State responsible for all the acts of the insurgents. ${ }^{141}$

Another basis of discussion (No. 22(d)) addressed the similar situation where damage is "caused to the person or property of a foreigner by persons taking part in a riot or by mob violence if the movement was directed against foreigners as such, or against persons of a particular nationality". ${ }^{142}$ Most states opined that in this scenario too, the state's responsibility depends on whether it failed to take all necessary measures under the standard of due diligence or whether there was negligence on its part. ${ }^{143}$

As it is well known, Article 10 ARSIWA codified the exceptional cases of attribution to a State of conduct of an insurrectional or other movement which subsequently becomes the new government of the state or succeeds in establishing a new state, with the implied main rule on non-attribution of the conduct of unsuccessful insurrectional movements to the state. As significant state practice on both non-responsibility for unsuccessful insurrectional movements

\footnotetext{
${ }^{137}$ Ibid., pp. 118 (Netherlands).

${ }^{138}$ Ibid., pp. 118 (Switzerland) ; ibid., Supplement to vol. III, p. 3 (Canada).

${ }^{139}$ Ibid., pp. 117 (Finland).

${ }^{140}$ Annuaire de l'Institut de droit international, supra note 52, pp. 142-143.

${ }^{141}$ C.75.M.69.1929.V, supra note 106, pp. 118.

142 Ibid., pp. 120

${ }^{143}$ Ibid., pp. 119-120.
} 
and State responsibility for successful insurrectional movements, the ARSIWA commentary refers to the preparatory work for the 1930 Hague Conference. ${ }^{144}$

\subsection{Subordinated States}

While orally not discussed, the question of state responsibility for the conduct of another state was subject to various comments and constitutes a very early state practice for the responsibility of a state in connection with the act of another state.

A deadlock of the discussion on attribution resulted from the proposed basis of discussion on the "responsibility of the State in the case of a subordinate or a protected State, a federal State or other unions of States". The request of commentaries regarding this point raised obvious confusion, as the formulation covered two different scenarios: the responsibility of a federal state for the conduct of its component, autonomous or federative units, on the one hand, and the responsibility of a state in connection with the act of another sovereign state, on the other. While the first scenario was not contested by states and experts of the LoN, ${ }^{145}$ the second led to controversies. Responsibility for the act of another state or also "indirect responsibility" in the reports of Roberto Ago, ${ }^{146}$ was a crucial question in both the interwar and the de-colonisation period, as dependent territories such as occupied states, mandated or trust territories constituted a high variety of subordinate interstate relationships. ${ }^{147}$ The responsibility of the protecting state for the wrongful conduct of the dependent entity was all the more complicated that some of the dependent territories in their pre-independence phase, before becoming states as a matter of international law, participated in international relations. For instance, some of those dependent entities were original members of the LoN (Australia, Canada, India, New Zealand, South Africa) and later the UN (India, Philippines, Lebanon and Syria).

Contemporary scholarship elaborated two rival views about the responsibility for the wrongs committed by dependent entities. According to the early dominant view, a state should be held responsible for the internationally wrongful act of another state if the latter, having accepted the domination of the former, conferred on it the right to represent it vis-a-vis third

\footnotetext{
${ }^{144}$ ARSIWA Commentary, supra note 58, pp. 50, para. 3 and 52, para. 13.

${ }^{145}$ E.g. Guerrero report, supra note 30, pp. 6, 16; C.75.M.69.1929.V, supra note 106, pp. 122 (Great Britain, Hungary), 123 (Italy, Norway), 123-124 (Switzerland).

${ }^{146}$ Eighth report on State responsibility, by Mr. Roberto Ago, Special Rapporteur. The internationally wrongful act of the State, source of international responsibility, UN Doc. A/CN.4/318 and Add.l to 4, in: vol. II(1) YbILC (1979) pp. 4-5.

${ }^{147}$ Ibid., pp. 5-6, para. 5.
} 
states in international relations. ${ }^{148}$ Some arbitrators ${ }^{149}$ and private codifications preceding The Hague conference ${ }^{150}$ also adopted this representation theory. The second, increasingly dominant view held the dominant state responsible not on account of representing the dependent entity in international relations, but on account of its effective power over the subordinated entity, "whether this involves a de jure relationship or even, in some opinions, a purely de facto one". ${ }^{151}$

States in The Hague were divided along and even beyond those existing schools, the representation theory and that of effective control. On the one hand, most states held that the state representing the wrongdoer state in its international relations should incur responsibility, ${ }^{152}$ while few states considered the wrongdoer State which performed the actual wrongful act as responsible. ${ }^{153}$ On the other hand, Denmark defended the theory of effectiveness and put the emphasis on the degree of control exercised by the dominant state over the subordinate state. ${ }^{154}$ This view became dominant among scholars including the later ILC rapporteur Ago from the $1930 \mathrm{~s},{ }^{155}$ recognising that the mere existence of the international representation relationship between two states had no consequences for third states, nor did it influence the subordinated state's capacity to provide reparation. Furthermore, state practice confirmed the theory of effectiveness. ${ }^{156}$ There has been no state practice however to confirm the assertion that a state, having undertaken the general and obligatory representation of another state, is for that reason alone indirectly responsible for internationally wrongful acts committed by the represented state. ${ }^{157}$

\footnotetext{
${ }^{148}$ Anzilotti (n 22) 146-147; Dionisio Anzilotti, 'La Responsabilité Internationale Des États à Raison Des Dommages Soufferts Par Des Étrangers' (1906) 13 Revue générale de droit international public 5, 300-301. and other authors cited in Eighth report of Ago, supra note 146, pp. 6 and footnote 11.

${ }^{149}$ Affaire des biens britanniques au Maroc espagnol (Espagne contre Royaume-Uni), UNRIAA, ${ }^{\text {st }}$ May 1925, vol. II, p. 648; PCIJ, Mavrommatis Palestine Concessions, Series A - No. 2, Judgment of 30 August 1924 (Objection to the Jurisdiction of the Court), p. 23.

${ }^{150}$ Institute of International Law, Resolution of 1927, supra note 55, Article IX(2); Draft prepared by the Harvard Law School, supra note 32, Article 3.

${ }^{151}$ Eighth report of Ago, supra note 144, pp. 5-6, para. 4.

${ }^{152}$ C.75.M.69.1929.V, supra note 106, pp. 121 (South Africa, Germany, Australia, Austria), 122 (Great Britain), 123 (Japan, Poland), 124 (Czechoslovakia); C.351(c)M.145(c).1930.V, supra note 22, pp. 212 (Finland), 221 (India), 231 (USA).

${ }_{153}$ C.75.M.69.1929.V, supra note 106, pp. 122 (Bulgaria).

${ }^{154}$ Ibid., pp. 122 (Denmark).

${ }^{155}$ Eighth report of Ago, supra note 144, pp. 7, para. 7; Clyde Eagleton, The Responsibility of States States in International Law (New York University Press 1928) 30-31.; for other authors, Eighth report of Ago, supra note 144, pp. 7, para. 8, n 16 and pp. 10, para. 13, and footnote 24.

${ }^{156}$ E.g. Robert E. Brown (United States) v. Great Britain, 23 November 1923, UNRIAA, vol. VI, pp. 130-131; Heinrich Finck c. Gouvernement Egyptien, Cour d'appel mixte d'Alexandrie, $1^{\text {st }}$ March 1927, in: 55 Journal du Droit International, (1928) p. 196; for other precedents including after 1945, see Eighth report of Ago, supra note 144, pp. 21-24, paras 34-41.

${ }^{157}$ Eighth report of Ago, supra note 144, pp. 9, para. 12.
} 
The logic scrutinizing the effective exercise of power or control was the test that the ILC finally adopted seven decades later while preparing Article 17 ARSIWA. ${ }^{158}$ While categories of dependencies between sovereign States have disappeared from State practice, the scenario resembles to the interstate relationship based on control that the ILC later called "direction and control exercised over the commission of an internationally wrongful act". 159 Therefore, The Hague codification is important as it marked an early turn from the representation theory towards effectiveness as the decisive test for the responsibility of a state in connection with the act of another state.

\section{Circumstances precluding wrongfulness}

Early scholarship of international law remarked the importance of certain circumstances precluding wrongfulness that would otherwise not be in conformity with the international obligations of the concerned State. International law scholars of the $17^{\text {th }}-18^{\text {th }}$ centuries managed to identify necessity, ${ }^{160}$ force majeure,${ }^{161}$ the state's inability to perform its obligation ${ }^{162}$ or self-defence ${ }^{163}$ as circumstances precluding the state's responsibility or wrongfulness. The early $20^{\text {th }}$ century positivist pioneers of the law of state responsibility equally took into account certain causes precluding wrongfulness such as necessity, ${ }^{164}$ without generalising the topic and systemising those circumstances. There was no clarity as to the question whether those scenarios precluded international responsibility ${ }^{165}$ or even the wrongfulness of the conduct, that is the breach of an international obligation. ${ }^{166}$ International law codifications before 1930 also failed to recognise the broader category, except for providing on the non-responsibility for wrongful acts of unsuccessful insurrections. ${ }^{167}$

\footnotetext{
${ }^{158}$ ARSIWA Commentary, supra note 58, pp. 69, para. 7.

159 Article 17 ARSIWA.

${ }^{160}$ Zouch (n 102) 111.

161 Ibid.

162 Cornelis van Bynkershoek, Quaestionum juris publici libri duo (Tenney Frank tr, Clarendon Press 1930) 193.

${ }^{163}$ Emer de Vattel, Le droit des gens; ou Principes de la loi naturelle, appliqués à la conduite et aux affaires des nations et des souverains, (Charles G Fenwick and Albert Geouffre de Lapradelle trs, Carnegie institution of Washington 1916) 272.

164 Anzilotti (n 149) 303-307.

165 E.g. De Visscher (n 58) 249.

166 Vattel (n 164) 272; Anzilotti (n 149) 304.

${ }^{167}$ Convention relative to the rights of aliens, supra note 1275, Article 2(2); Draft prepared by the Harvard Law School, supra note 32, Article 13(a); Institute of International Law, Resolution of 1927, supra note 55, Article VII(1).
} 
The major achievement in the LoN's codification process was the recognition of the broader category: the Preparatory Committee inserted various points of discussion under the title "circumstances under which States can decline their responsibility", constituting the very first attempt to codify circumstances precluding wrongfulness. Only two states objected to this subject matter, claiming that it would be difficult to determine and regulate the cases in which a State might be exempted from responsibility. ${ }^{168}$ All other commenting states consented to the theme and accepted some circumstances that would exclude responsibility.

Among the specific circumstances, the Preparatory Committee addressed to states questions regarding self-defence, ${ }^{169}$ reprisals, ${ }^{170}$ unilateral abrogation of treaties between states, ${ }^{171}$ contractual undertaking by a private person not to have recourse to the diplomatic remedy, ${ }^{172}$ and exhaustion of domestic remedies. ${ }^{173}$ The latter three topics did not become part of the contemporary canon of circumstances precluding wrongfulness, but two of them found some echo in later codifications. First, states in the LoN's codification process were divided as to unilateral abrogation of treaties between states as a circumstance excluding responsibility and the Preparatory Committee considered it as a question of investment treaties (a concession granted by the state or a contract concluded between the state and the foreigner), without the need to codify a special rule of state responsibility. ${ }^{174}$ In line with this logic and despite the inherent link of the rebus sic stantibus rule with state responsibility, ${ }^{175}$ the ILC has considered it as a question of the law of treaties rather than that of state responsibility and inserted it in the Vienna Convention on the Law of Treaties. ${ }^{176}$ Second, a contractual undertaking by a private person not to have recourse to the diplomatic remedy led to the recognition of a negative rule, excluding that such an undertaking could bind the state of nationality and influence the responsibility of the wrongdoer state. ${ }^{177}$ As the discussion focused on the permissibility and effect of the so-called Calvo clause, often interpreted as a waiver of the right of the state of nationality to provide diplomatic protection in respect of a wrongful act of the host state, the

\footnotetext{
${ }^{168}$ C.75.M.69.1929.V, supra note 29, pp. 125 (Egypt), 127, 130, and 132 (Poland).

${ }^{169}$ Ibid., pp. 128 (Point XI(a)/Basis of Discussion No. 24).

${ }^{170}$ Ibid., pp. 130 (Point XI(b)/Basis of Discussion No. 25).

${ }^{171}$ Ibid., pp. 131 (Point XI(c)/no specific basis of discussion prepared).

172 Ibid., pp. 134 (Point XI(d)/Basis of Discussion No. 26).

${ }^{173}$ Ibid., pp. 136 (Point XI(d)/Basis of Discussion No. 27).

${ }^{174}$ Ibid., pp. 133.

${ }^{175}$ E.g. ILC, 694 ${ }^{\text {th }}$ Meeting, 6 June 1963, vol. I YbILC, (1963) pp. 142, para. 70 (Mr. Pessou); ARSIWA

Commentary, supra note 58, pp. 83, para. 14 (the stringency and the negative wording of both Article 25

ARSIWA and Article 62 VCLT).

176 Article 62 (Fundamental change of circumstances), Vienna Convention on the Law of Treaties.

177 C.75.M.69.1929.V, supra note 29, pp. 135 (Basis of Discussion No. 26).
} 
negative opinion of most States in The Hague helped the ILC to leave it aside from the exhaustion of domestic remedies rule in the law of diplomatic protection. ${ }^{178}$ Third, the exhaustion of local remedies rule, unanimously supported by states in The Hague, ${ }^{179}$ has become part of the ARSIWA under the chapter "invocation of the responsibility of a State". ${ }^{180}$ Two other scenarios, self-defence (5.1) and reprisals (5.2), merit further attention as they have become part of the ARSIWA chapter on circumstances precluding wrongfulness.

\subsection{Self-defence}

While most states in le LoN's codification process accepted self-defence as a circumstance excluding unlawfulness, some also required liability for the lawfully caused damage. ${ }^{181}$ States defined situations of self-defence in different ways, some applying it to insurrections within the state, ${ }^{182}$ others to unlawful attack by states, ${ }^{183}$ or exceptionally by private persons, ${ }^{184}$ and even to acts occurring outside the national territory but capable of compromising the state's security (such as the Caroline case in 1837). ${ }^{185}$ This divergence is explained by the fact that the question was whether self-defence could be regarded as a circumstance precluding the wrongfulness of state conduct in the area of responsibility for the failure to protect foreign nationals rather than for acts committed directly against a foreign state. ${ }^{186}$ Moreover, certain states unsurprisingly expressed doubts about the feasibility to agree on an international definition of aggression. ${ }^{187}$

Based on the states' comments, the Preparatory Committee limited its discussion to self-defence within the state's own territory and avoided the state's responsibility for damage caused to foreigners in the exercise of self-defence outside its territory that it considered falling within the laws of war. ${ }^{188}$ Its basis of discussion on self-defence provided as follows:

\footnotetext{
${ }^{178}$ ILC, Third report on diplomatic protection, by Mr. John Dugard, Special Rapporteur, vol. II(1) YbILC, (2002) pp. 78, para. 136 (taking into account State comments of The Hague); Diplomatic protection: Draft articles with commentaries, vol. II(2) YbILC, (2006) pp. 45, para. 8.

${ }^{179}$ Ibid., pp. 136-139.

${ }^{180}$ Article 44(b) ARSIWA

${ }^{181}$ C.75.M.69.1929.V, supra note 29, pp. 125 (South Africa), 126 (Great Britain, India), 127 (New Zealand).

182 Ibid., pp. 125 (South Africa).

${ }^{183}$ Ibid., pp. 125 (Belgium).

${ }^{184}$ Ibid., pp. 126 (Denmark).

${ }^{185}$ Ibid., (Denmark).

${ }^{186}$ ILC, Draft articles on State responsibility, vol. II(2) YbILC, (1980) pp. 57, para. 14, and footnote 202.

${ }^{187}$ C.75.M.69.1929.V, supra note 29, pp. 127 (Switzerland).

${ }^{188}$ Ibid., pp. 127-128.
} 
A State is not responsible for damage caused to a foreigner if it proves that its act was occasioned by the immediate necessity of self-defence against a danger with which the foreigner threatened the State or other persons.

Should the circumstances not fully justify the acts which caused the damage, the State may be responsible to an extent to be determined. ${ }^{189}$

While the conference did not have time to discuss the proposed topic, some aspects of the basis of discussion have had long-term impact on developments of international law. South Africa proposed to limit the non-responsibility for the damage caused in the exercise of "the preservation of the public peace and security" to conduct not exceeding "the reasonable requirements of the situation", ${ }^{190}$ thereby foreseeing the proportionality requirement of selfdefence, crystallized after WWII. ${ }^{191}$ The second paragraph of the basis of discussion inspired the first ILC rapporteur on state responsibility, Gracía-Amador, who considered that "[o]wing to their analogy with the case of self-defence, it may be considered that the extent of responsibility may also vary in cases of force majeure and necessity". ${ }^{192}$ Based on this analogy, his draft provided that force majeure and state of necessity, "if not admissible as grounds for exoneration from responsibility, shall operate as extenuating circumstances". ${ }^{193}$ Whereas his draft article on force majeure and state of necessity absorbed self-defence, his successors maintained a separate article for self-defence, citing both the states' comments and basis of discussion prepared in the LoN's codification process. ${ }^{194}$

The point to emphasize here is not the lasting impact of the primary norm content of self-defence as understood in the interwar period, ${ }^{195}$ but the idea that the use of force in selfdefence precludes the wrongfulness of the acts in which force is so used. As the first ILC special rapporteur on state responsibility noted, after the adoption of the UN Charter, "the right of selfdefence, at all times recognized as one of those exercisable by the State for its own preservation,

\footnotetext{
${ }^{189}$ C.75.M.69.1929.V, supra note 29, pp. 128 (Basis of Discussion No. 24).

${ }^{190}$ C.351(c)M.145(c).1930.V, supra note 22, pp. 229.

${ }^{191}$ Military and Paramilitary Activities in und against Nicaragua (Nicaragua v. United States of America). Merits, Judgment. I.C.J. Reports 1986, p. 94, para. 176; Legality of the Threat or Use of Nuclear Weapons, Advisory Opinion, I.C.J. Reports 1996, p. 245, para. 41.

${ }^{192}$ International responsibility: report by F. V. Garcia Amador, Special Rapporteur, vol. II YbILC, (1956) pp. 208, para. 185.

${ }^{193}$ International responsibility: Sixth report by F. V. Garcia Amador, Special Rapporteur, vol. II YbILC, (1961) pp. 48, Draft Article 17(4).

${ }^{194}$ Eg Draft articles on State responsibility, vol. II(2) YbILC, (1980) pp. 56-57, para. 14; see the same wording in Draft articles on State responsibility adopted on first reading by the Commission, in: vol. II(2) YbILC, (1996) pp. 58-65, draft Article 34; ARSIWA Commentary, supra note 58, pp. 71-72, para. 5.

195 The LoN's codification process influenced in substance certain private codifications in the interwar period. 1930 draft of the German International Law Association, supra note 32, Article 16.
} 
has become subject to the conditions laid down in Article 51 of the Charter". ${ }^{196}$ The substantive law understanding of self-defence before 1945 certainly differed from that under the UN Charter, and this was reflected in the above-mentioned diverging state comments on the nature of self-defence. However, the latter has evolved with the gradual affirmation of the principle of the prohibition of recourse to war and as a necessary exception to that principle, enshrined in interwar instruments such as the Covenant of the LoN or the Kellogg-Briand Pact. Until the final outcome of the ILC works on State responsibility, the Commission and the special rapporteurs on state responsibility took into account the state comments expressed in the LoN's codification process and integrated the idea of a circumstance precluding wrongfulness in Article 21 ARSIWA.

\subsection{Reprisals}

On the other proposed circumstance, reprisals, states had even more diverse views. Generally speaking, reprisals are understood as a 'course of conduct which is not in conformity with the terms of an international obligation and has been adopted in certain circumstances by a State towards another State which has previously breached an international obligation towards it". 197 A Commission of Jurists appointed by the LoN in 1923 following the Italian-Greek Corfu incident impliedly accepted non-armed reprisals as lawful measures. ${ }^{198}$ After that report, LoN member states debated only about the lawfulness of armed reprisals short of war. ${ }^{199}$

In the codification process, some states defined situations where reprisals are lawful by adding criteria beyond the mere violation of an international obligation by another state. For instance, Belgium submitted that a reprisal shall be "proportionate to the gravity of the violation, provided that the State cannot obtain satisfaction by pacific means". ${ }^{200}$ Denmark held that reprisals "can only be lawful when the stipulations of the Covenant have been previously fulfilled and the prescribed time limits observed". ${ }^{201}$ For the Swiss government, "reprisals should only be admitted provided the State resorting thereto possesses no other pacific means

\footnotetext{
${ }^{196}$ International responsibility: Third report by F. V. García Amador, Special Rapporteur, vol. II YbILC, (1958) pp. 53, para. 15; While self-defence under Article 51 concerned armed conflicts, his draft was concerned "exclusively with cases of responsibility in peacetime". Ibid.

${ }^{197}$ Eighth report of Ago, supra note 144, pp. 41, para. 88.

${ }^{198}$ Report of the Commission of Jurists, 5 League of Nations Official Journal (1924), pp. 521, 524.

${ }^{199}$ See a summary of State practice in: Herbert W Briggs (ed), The Law of Nations. Cases, Documents, and Notes (2nd Edition edition, Appleton-Century-Crofts 1952) 962-964.

${ }^{200}$ C.75.M.69.1929.V, supra note 29, pp. 128.

${ }^{201}$ Ibid.
} 
of reacting when injured by a violation of the law."202 The Czechoslovak government, finally, proposed that an impartial and independent international tribunal should review "whether the conditions necessary for a just defence or for reprisals" were actually present. ${ }^{203}$

The Preparatory Committee declined to reflect on "whether reprisals can today be justified, and between what states and in what circumstances they can be justified", and limited its work on a rather general basis of discussion. ${ }^{204}$ It provided that:

[a] State is not responsible for damage caused to a foreigner if it proves that it acted in circumstances justifying the exercise of reprisals against the State to which the foreigner belongs. ${ }^{205}$

Both the LoN's codification experts and the ILC have considered reprisal as a circumstance precluding lawfulness, and thus lawful conduct, although the contemporary law of state responsibility uses the term "countermeasures". ${ }^{206}$ The UN Charter and UN instruments such as the 1970 Declaration on Principles of International Law limited however countermeasures to peaceful ones by banning the use of armed reprisals ${ }^{207}$ - a limitation that Denmark also proposed in the LoN's codification procedure. ${ }^{208}$

To confirm the definition of countermeasures, early ILC drafts ${ }^{209}$ and the ARSIWA Commentary ${ }^{210}$ also refer to the state comments prepared in the LoN's codification process. In line with the idea to limit reprisals, as expressed by certain delegations in the LoN's codification process, ILC special rapporteurs also required reprisals to be proportionate. ${ }^{211}$ This subsequent practice shows that the LoN's codification work on self-defence has also anticipated later codification developments.

The last ILC Special rapporteur of state responsibility, James Crawford recognised the state comments and bases of discussion in the LoN's codification process, ${ }^{212}$ and referred to them in the commentary of the ARSIWA rules on circumstances precluding wrongfulness. ${ }^{213}$

\footnotetext{
202 Ibid., pp. 130.

${ }^{203}$ Ibid.

${ }^{204}$ Ibid., pp. 130.

${ }^{205}$ Ibid. (Basis of Discussion No. 25).

${ }^{206}$ ARSIWA Commentary, supra note 58, pp. 75. Para. 3.

${ }^{207}$ Eighth report of Ago, supra note 144, p. 49, para. 89.

${ }^{208}$ C.75.M.69.1929.V, supra note 29, p. 129.

${ }^{209}$ Ibid., pp. 41-42, para. 88.

${ }^{210}$ ARSIWA Commentary, supra note 58, pp. 130, para. 2, and footnote 745.

${ }^{211}$ Eighth report of Ago, supra note 144, pp. 40, para. 82.

${ }^{212}$ Second report on State responsibility, by Mr. James Crawford, Special Rapporteur, vol. II(1) YbILC, (1999) pp. 57, para. 217(a).

${ }^{213}$ ARSIWA Commentary, supra note 58, pp. 71-72, para. 5.
} 
It is true that in The Hague, neither states nor the Preparatory Committee specified whether the discussed circumstances excluded state responsibility or even the wrongfulness of the conduct. As Ago explained, the distinction was not considered at the time as having any practical importance, ${ }^{214}$ but the above-mentioned comments indicate that some states were ready to distinguish between the operation of primary norms, on the one hand, and that of secondary norms, on the other. ${ }^{215}$ As the ILC conceptualised circumstances precluding wrongfulness in a relatively mature phase of its work, ${ }^{216}$ after various changes in classifying those scenarios as questions of primary or secondary norms, ${ }^{217}$ the pioneering drafts and dialogue in the LoN's codification process are remarkable.

\section{Conclusions}

Within the LoN's codification process, the written and oral dialogue of states and experts on state responsibility has established the foundations of a truly universal codification discussion that has continued until today. Despite the lack of a single outcome document at the end of The Hague conference in 1930 such as a draft treaty or report, the LoN's codification clarified certain general and particular concepts, principles or norms of state responsibility that have become part of contemporary international law.

First, the working methods and the publicity of the LoN's codification procedure galvanised the interwar debates of international lawyers on the law of state responsibility. Moreover, they helped the ILC in adopting similar working methods and referencing the discussions as authoritative source of state practice.

Second, among general principles, the international wrongfulness of the conduct and attribution were confirmed as the constitutive elements of state responsibility, reflecting the early $20^{\text {th }}$ century development of state practice. Besides, the LoN's delegates managed to eliminate limitless debates on the requirement of fault or damage as further constitutive

\footnotetext{
${ }^{214}$ Eighth report of Ago, supra note 144, pp. 29, para. 53.

${ }^{215}$ Eg C.75.M.69.1929.V, supra note 29, pp. 131 (Austria).

216 Draft Article 1, in: vol. II YbILC, (1973) pp. 176, para. 12; a contrario, in the first report on the issue, the Special Rapporteur distinguished between "exonerating grounds properly so called", on the one hand, "and other grounds which may be considered as extenuating or aggravating circumstances", on the other. Report on International Responsibility by Mr. F.V. Garcia-Amador, Special Rapporteur, vol. II YbILC, (1956) pp. 209, para. 191.

${ }^{217}$ E.g. Sir Gerald Fitzmaurice in his fourth report on the law of treaties identified a list of "circumstances justifying non-performance", covering most of the cases accepted today as circumstances precluding wrongfulness (e.g. "acceptance of non-performance by the other party or parties", "force majeure", "legitimate military self-defence", and "non-performance by way of legitimate reprisals"). Fourth report by Sir Gerald Fitzmaurice, Special Rapporteur, vol. II YbILC, (1959) pp. 62-70.
} 
elements of state responsibility, and thereby anticipated the contemporary dominant opinion under which those elements follow from the primary obligations rather than from secondary norms.

Third, the LoN's codification clarified some of the secondary norms that are nowadays accepted as part of the law of state responsibility. The particular norms mentioned in the areas of attribution and circumstances precluding wrongfulness are only examples that have been integrated in the contemporary canon of the rules of state responsibility. Several other rules of the LoN's codification process could have been mentioned as they not only anticipated the ILC's ARSIWA, but were referred to by court decisions as such. Examples include the state's responsibility for the wrongful conduct of its domestic tribunals, ${ }^{218}$ or the requirement of exhaustion of domestic remedies. ${ }^{219}$

In conclusion, instead of considering The Hague conference as a failure, it is more just to regard the entire LoN's process as the pioneering start and benchmark of a century-long development of the law of state responsibility. The lasting impact of the concepts, principles or norms of state responsibility clarified in the LoN's codification process confirms the pioneering work of the LoN.

\footnotetext{
${ }^{218}$ C.75.M.69.1929.V, supra note 29, pp. 48, 51 (Bases of Siscussion 5-6); Text adopted in first reading, supra note 45, pp. 237, Article 9]; cited in: International Fisheries Company (U.S.A.) v. United Mexican States, UNRIAA, Vol. IV, July 1931, p. 694.

${ }^{219}$ C.75.M.69.1929.V, supra note 29, pp. 136-139 (Point XII/Basis of Discussion No. 27); State comments cited in: Mexican Union Railway (Limited) (Great Britain) v. United Mexican States, Decision No. 21, February, 1930, UNRIAA, Vol. V, p. 122.
} 